\title{
Komunikasi Matematis Tulis Siswa melalui Penerapan Pendekatan Student Center Learning
}

\author{
Nurhayati $^{1}$, Sudirman $^{1}$, Sukoriyanto ${ }^{1}$ \\ ${ }^{1}$ Pendidikan Matematika-Universitas Negeri Malang
}

\section{INFO ARTIKEL}

Riwayat Artikel:

Diterima: 26-02-2019

Disetujui: 25-07-2019

\section{Kata kunci: \\ mathematical communication; student center learning approach; komunikasi matematis; pendekatan student center learning}

\section{ABSTRAK}

Abstract: The Classroom Action Research aims is to describe implementation of student center learning instruction that can increase written mathematical communication of senior high school students. This research is conducted in two cycles. The result of this reserach indicates that students written mathematical communications skills increase from cycle I to cycle II. Student center learning instruction consists of organise information, organise questions, solve the problem, present the discussion results, reflect, and mastery test material.

\begin{abstract}
Abstrak: Penelitian tindakan kelas ini bertujuan mendeskripsikan penerapan pendekatan student center learning untuk meningkatkan kemampuan komunikasi matematis tulis siswa SMA. Penelitian dilakukan dalam dua siklus. Hasil penelitian menunjukkan bahwa kemampuan komunikasi matematis tulis siswa meningkat dari siklus I ke siklus II. Pendekatan student center learning dilakukan secara diskusi kelompok terdiri atas mengumpulkan informasi, mengorganisir pertanyaan, menyelesaikan masalah, menyajikan hasil diskusi, refleksi, dan tes penguasaan materi.
\end{abstract}

\author{
Alamat Korespondensi: \\ Nurhayati \\ Pendidikan Matematika \\ Universitas Negeri Malang \\ Jalan Semarang 5 Malang \\ E-mail: yati421@gmail.com
}

Matematika merupakan dasar banyak hal yang membantu manusia mengambil keputusan dalam kehidupannya. Pengajaran dan pembelajaran matematika adalah inti dari pendidikan. Tujuan pembelajaran matematika di sekolah adalah mengaitkan sekolah dengan kehidupan sehari-hari siswa, memberikan penguasaan keterampilan, dan menyiapkan siswa memiliki keterampilan berpikir dan sebagai tenaga kerja. Matematika melibatkan pembelajaran untuk pemecahan masalah, menyelidiki, representasi, mengomunikasikan konsep dan ide-ide serta menghubungkannya dengan dunia nyata (Erhan \& Nahornick, 2016). Matematika juga sebagai salah satu sarana mengembangkan kemampuan komunikasi sehingga pembelajaran yang dilaksanakan pada suatu sekolah harus dapat mengembangkan kemampuan komunikasi, salah satunya adalah komunikasi matematis tulis.

Komunikasi matematis tulis merupakan aktivitas intelektual yang menghendaki siswa untuk menyampaikan ide-ide atau pemikiran matematisnya secara tertulis. Tulisan merupakan sarana untuk menggambarkan ide-ide, hubungan, keadaan, atau penjelasan matematis, dan menyajikan ide-ide abstrak dalam bentuk sehingga dapat dibaca dan digunakan orang lain (Pantaleon, dkk., 2018). Komunikasi matematis dalam bentuk tulisan berdasarkan pada (1) pemahaman terhadap konsep, (2) penggunaan model matematika, dan (3) penggunaan notasi dan istilah matematika (Cai, Jakabcsin, \& Lane, 2016).

NCTM menyatakan komunikasi merupakan hal penting pada matematika dan pendidikannya. Terdapat empat indikator kemampuan komunikasi yang seharusnya dikuasai siswa, yaitu (1) menggunakan komunikasi sebagai alat untuk mengorganisasikan pemikiran matematis mereka; (2) mengomunikasikan ide dan gagasan matematika secara runtut, jelas, dan tepat kepada lawan komunikasi; (3) menganalisa dan mengevaluasi ide matematis dan strategi yang digunakan orang lain; (4) menggunakan bahasa matematika untuk mengekspresikan ide-ide matematis dengan tepat. (NCTM, 2000). Kemampuan komunikasi penting bagi siswa sesuai dengan salah satu tujuan pembelajaran matematika yaitu siswa memiliki kemampuan mengomunikasikan gagasan matematika dengan jelas dan efektif (Kemendikbud, 2016).

(Baroody, 1993) menyatakan dua alasan kemampuan komunikasi penting dalam pembelajaran, yaitu mathematics as language and mathematics learning as social activity. Matematika sebagai bahasa yaitu matematika berperan sebagai alat bantu berpikir, alat untuk menemukan pola, atau menyelesaikan masalah, serta alat untuk mengomunikasikan ide-ide secara tepat, jelas, dan ringkas. Pembelajaran matematika sebagai aktivitas sosial yaitu adanya interaksi antar siswa, interaksi guru dan siswa merupakan bagian penting untuk memelihara dan mengembangkan potensi matematika siswa. Demikian pula (Rajagukguk, 2016) menyatakan bahwa pentingnya kemampuan komunikasi matematis bagi siswa adalah untuk meningkatkan keterampilan matematisnya, terutama dalam mengomunikasikan ide-ide dengan simbol, tabel, diagram atau media lain untuk mengklarifikasi situasi atau masalah matematis. 
Selain itu, komunikasi merupakan salah satu kemampuan yang perlu dikembangkan untuk menghadapi abad 21. Kemampuan komunikasi yang dikembangkan meliputi bagaimana berkomunikasi secara efektif, lisan maupun tulisan, dan keterampilan mendengarkan (Education, 2016). Kenyataannya, siswa SMA masih yang memiliki kemampuan komunikasi rendah. Hal ini dapat dilihat ketika peneliti melakukan observasi awal di salah satu SMA di Pacitan. Peneliti memberikan masalah sistem persamaan linier dua variabel kepada siswa kelas X sebagai berikut: Tahun lalu, sekolah membeli kaos kaki dan celana pendek untuk tim bola voli putera. Harga kaos kaki Rp15.000,00/pasang dan harga satu celana pendek Rp50.000,00. Jumlah total yang harus dibayar Rp650.000,00. Tahun ini, sekolah membayar Rp730.000,00 untuk pembelian kaos kaki dan celana pendek dengan jumlah yang sama dengan tahun lalu. Hal ini dikarenakan sekarang harga sepasang kaos kaki Rp18.000,00 dan harga satu celana pendek Rp55.000,00. a) Tulislah model matematika dari permasalahan tersebut. b) Berapakah banyaknya kaos kaki dan celana pendek yang dibeli sekolah setiap tahun?

Salah satu proses penyelesaian soal siswa tersaji pada gambar 1. Siswa tersebut dapat mengomunikasikan informasi penting yang terdapat pada soal. Yaitu harga kaos kaki, celana pendek, dan total pembayaran pada tahun lalu serta tahun ini. Langkah pertama yang dilakukan siswa adalah mendefinisikan variabel. Terdapat $75 \%$ siswa mampu mendefinisikan variabel tetapi kurang lengkap dan hanya $40 \%$ siswa yang mampu menyusun model matematikanya dengan benar. Bahkan hanya 5\% saja siswa yang mampu menyelesaikan soal tersebut hingga diperoleh simpulan yang benar tentang banyaknya kaos kaki dan celana pendek yang dibeli sekolah tahun ini. Ini disebabkan pada proses pembelajaran, guru hanya menjelaskan proses hitungannya, tanpa memberikan kesempatan kepada siswa untuk mengemukakan ide-idenya secara tertulis.

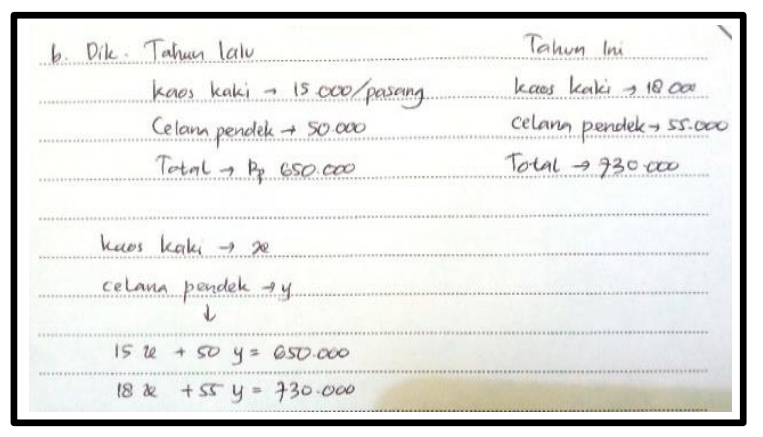

Gambar 1. Lembar Jawaban Siswa

Penelitian yang dilakukan oleh (Saragih, 2007) menyatakan bahwa penyebab rendahnya komunikasi siswa diantaranya adalah monotonnya pembelajaran dan sangat jarangnya partisipasi siswa. Kurangnya pengetahuan siswa akan materi prasyarat dan kurangnya partisipasi siswa dalam pembelajaran juga menjadi penyebab rendahnya komunikasi matematis tulis siswa. Oleh karena itu perlu dicarikan pemecahan masalah bagaimana melibatkan siswa secara aktif dalam pembelajaran dan bagaimana merancang pembelajaran yang dapat mengakses kemampuan komunikasi matematis tulis siswa.

Pembelajaran merupakan komunikasi dua arah antara siswa dan guru, siswa belajar lebih banyak dari guru dan guru juga belajar dari siswa. (Kaput, 2018) menyatakan sudah saatnya model pembelajaran di sekolah didesain dengan siswa sebagai pusat pembelajaran (student at the center). Pendekatan student center learning merupakan pendekatan pembelajaran dimana siswa sebagai pusat proses pembelajaran yang difasilitasi oleh guru melalui kegiatan dan tugas. Pada pendekatan ini siswa diharapkan membangun pengetahuannya sendiri. Pendekatan ini berdasarkan teori konstruktivisme. Menurut teori ini siswa membangun pengetahuannya sendiri dari pengalaman belajarnya dalam rangka belajar secara efektif (Hsiao, dkk., 2017; Attard, dkk, 2010). (Martell, 2015) juga menyatakan bahwa pembelajaran yang terpusat pada siswa juga merupakan satu metode untuk mendorong lingkungan kelas yang fleksibel dan kreatif.

Adapun tahapan-tahapan pada pendekatan student center learning yang dilaksanakan secara diskusi kelompok adalah sebagai berikut: (1) mengumpulkan informasi, (2) mengorganisir pertanyaan, (3) menyelesaikan masalah, (4) menyajikan hasil diskusi, (5) refleksi, (6) tes penguasaan materi. Pendekatan ini dilandasi prinsip- prinsip Student Center Learning yang dikemukakan oleh Attard (2010) dan karaketeristiknya oleh (Jacobs, Renandya, \& Power, 2016).

Berdasarkan paparan di atas, diperlukan pendekatan yang berpusat pada siswa dan mampu mengakses kemampuan komunikasi matematis siswa, utamanya komunikasi matematis tulis. Oleh karenanya, peneliti merumuskan masalah penelitian yaitu bagaimana langkah-langkah pendekatan Student Center Learning yang dapat meningkatkan kemampuan komunikasi matematis tulis siswa SMA.

\section{METODE}

Desain penelitian ini adalah Penelitian Tindakan Kelas. Peneliti berperan sebagai pelaku tindakan pelaksanaan kegiatan pembelajaran di kelas. Peneliti dibantu seorang guru matematika dan teman sejawat sebagai observer/pengamat selama kegiatan berlangsung. Data yang didapatkan dikumpulkan, dianalisis, dan ditarik kesimpulan oleh peneliti untuk selanjutnya dilakukan perbaikan pada siklus berikutnya jika masih terdapat kekurangan. 
Pelaksanaan penelitian ini mengacu pada desain siklus PTK model Kemmis \& McTaggart. Setiap siklus terdiri dari empat tahap. Banyaknya siklus yang dilaksanakan ditentukan oleh hasil refleksi dari siklus sebelumnya. Apabila hasil refleksi menunjukkan hasil penelitian sudah sesuai dengan kriteria pencapaian, maka siklus tidak perlu diulang. Sebaliknya, apabila kriteria pencapaian penelitian belum tercapai maka siklus diulang hingga mencapai kriteria yang telah ditetapkan.

Peneliti menggunakan pendekatan student center learning dengan model diskusi kelompok pada pembelajarannya. Data yang digunakan adalah instrumen penelitian yang telah divalidasi meliputi hasil observasi aktivitas guru, hasil observasi aktivitas siswa, hasil tes akhir siklus terkait kemampuan komunikasi matematis tulis siswa, serta hasil catatan lapangan observer selama penelitian.

Penelitian ini menggunakan analisis data kualitatif yaitu mereduksi data, menyajikan data dan menarik kesimpulan. Analisis data ini diterapkan pada data yang berupa catatan lapangan selama pelaksanaan penelitian. Sedangkan data berupa hasil observasi aktivitas guru, hasil observasi aktivitas siswa, dan nilai tes akhir siklus dihitung persentase skor rata-ratanya untuk menentukan kategorinya. Persentase $25 \leq S K<43,75$ masuk kategori tidak baik, persentase 43,75 $\leq S K<62,5$ masuk kategori kurang baik, persentase $62,5 \leq S K<82,5$ masuk kategori baik, persentase $81,25 \leq S K \leq 100$ masuk kategori sangat baik. Sedangkan kategori kemampuan komunikasi matematis tulis ditentukan berdasarkan persentase skor akhir dari tes akhir siklus kemampuan komunikasi matematis tulis. Penentuan kategorinya didasarkan pada skala berikut ini: $25 \% \leq K M<43,75 \%$ masuk kategori tidak baik, 43,75\% $\leq K M<62,5 \%$ masuk kategori kurang baik, $62,5 \% \leq K M<82,5 \%$ masuk kategori baik, $81,25 \% \leq K M \leq 100 \%$ masuk kategori sangat baik. Indikator keberhasilan tindakan pada penelitian ini (1) hasil observasi aktivitas guru dan siswa mendapatkan kategori minimal baik; (2) hasil tes akhir siklus kemampuan komunikasi matematis menunjukkan bahwa 75\% atau lebih siswa dapat mencapai minimal kategori baik. Apabila salah satu kriteria tersebut belum terpenuhi, maka dilaksanakan siklus berikutnya.

\section{HASIL}

Penelitian ini dilaksanakan dalam dua siklus dengan tahapan pada masing-masing siklus yaitu perencanaan (plan), pelaksanaan (act), pengamatan (osberve) dan refleksi (reflect).

\section{Siklus I \\ Perencaan Tindakan}

Peneliti melakukan segala persiapan yang akan digunakan pada penelitian ini. Perencanaan yang dilakukan adalah menyusun perangkat pembelajaran berupa RPP lengkap dan validasinya, membuat instrumen penelitian beserta validasinya, menentukan jadwal penelitian, serta menentukan observer yang akan membantu mengamati aktivitas guru dan siswa selama pelaksanaan penelitian.

\section{Pelaksanaan Tindakan}

Pelaksanaan tindakan pada siklus I sebanyak empat kali pertemuan, yaitu tanggal 22, 24, 29, dan 30 Oktober 2018. Kegiatan pembelajaran dilaksanakan selama tiga kali dan pada pertemuan keempat dilaksanakan tes akhir siklus yang sesuai dengan indikator kemampuan komunikasi matematis tulis siswa. Satu kali pertemuan dilaksanakan dalam 2 x 45 menit.

Pertemuan pertama dilaksanakan pada tanggal 22 Oktober 2018. Guru mengawali kegiatan dengan memberikan motivasi kepada siswa, menyampaikan cara penilaian pada pembelajaran dengan pendekatan student center learning, pengecekan pengetahuan awal, dan pembentukan kelompok. Setiap kelompok terdiri empat siswa dengan kemampuan komunikasi matematis tulis yang berbeda-beda (kelompok heterogen).

Kegiatan inti pada pertemuan pertama membahas tentang bagaimana menyusun model matematika dari masalah kontekstual. Model matematika yang disusun berbentuk sistem persamaan linier tiga variabel. Kegiatan ini diawali dengan tahap pengamatan, yaitu siswa mengamati masalah yang disajikan pada lembar kegiatan siswa. Selanjutnya, siswa mengumpulkan informasi penting, mengorganisir pertanyaan dan menyelesaikan masalah yang disajikan. Penyelesaian dari masalah yang disajikan adalah dengan mendefinisikan variabel-variabelnya dan menyusun model matematika dari masalah kontekstual yang diberikan. Ada tiga bahan diskusi yang didiskusikan siswa pada pertemuan pertama.

Indikator kemampuan komunikasi matematis tulis siswa yang ditingkatkan pada pertemuan pertama adalah mendefinisikan variabel dan menyusun model matematika dari suatu masalah kontekstual. Pertemuan pertama, siswa perlu beradaptasi dengan pembelajaran yang diterapkan dan waktu yang lebih banyak saat menyusun model matematika. Setelah semua bahan diskusi terselesaikan, guru membimbing siswa untuk menyajikan hasil diskusi kelompok kepada kelompok lain. Setelah penyajian selesai, guru bersama siswa menyimpulkan kegiatan pembelajaran yang dilaksanakan. Kegiatan pembelajaran ditutup dengan refleksi bersama siswa dan guru mengenai pencapaian apa yang telah dipelajarinya.

Pertemuan kedua dilaksanakan pada tanggal 24 Oktober 2018. Seperti pada pertemuan pertama, kegiatan pembelajaran diawali dengan pemberian motivasi kepada siswa hingga pengaturan siswa dalam kelompok. Kelompok belajar pada pertemuan kedua sama dengan pertemuan pertama. Indikator komunikasi matematis yang dikembangkan pada pertemuan kedua adalah menuliskan gagasan/ide penyelesaian dan simpulan penyelesaian yang diperoleh suatu masalah kontekstual. Kegiatan inti pada pertemuan ini adalah siswa menentukan penyelesaian sistem persamaan linier tiga variabel dengan gabungan metode eliminasi 
dan substitusi. Bahan diskusi yang kedua adalah siswa diminta menentukan persamaan grafik dari persamaan $y=a x^{2}+b x+c$ yang melalui tiga titik $(1,-1),(3,23),(-1,7)$. Siswa mengalami kesulitan ketika menghubungkan titik-titik yang dilalui dengan persamaan grafik tersebut. Guru mengingatkan kepada siswa tentang titik koordinat dan meminta siswa menghubungkan dengan persamaan yang diketahui sehingga diperoleh persamaan linier tiga variabel. Setelah siswa menyelesaikan tiga permasalahan yang ada di lembar kegiatan, guru membimbing siswa untuk menyajikan hasil diskusinya kepada kelompok lain.

Setelah penyajian hasil diskusi, guru bersama siswa menyimpulkan kegiatan pembelajaran yang telah dilaksanakan dan melakukan tes penguasaan materi. Tes ini untuk mengetahui kemajuan belajar siswa pada setiap pertemuan. Selanjutnya, kegiatan pembelajaran ditutup dengan refleksi dan guru mengingatkan kepada siswa untuk mengerjakan soal tantangan di lembar kegiatan bersama kelompoknya.

Pertemuan ketiga dilaksanakan pada tanggal 29 Oktober 2018. Pembelajaran diawali dengan pemberian motivasi berupa penerapan sistem persamaan linier tiga variabel dalam kehidupan sehari-hari. Kelompok belajar pada pertemuan ketiga berubah sesuai dengan hasil tes penguasaan materi pada pertemuan kedua. Kegiatan inti pada pertemua ketiga adalah menyelesaikan masalah kontekstual yang berkaitan dengan sistem persamaan linier tiga variabel. Permasalahan pada pertemuan ketiga dirancang memiliki banyak jawaban benar. Pertemuan keempat dilaksanakan pada tanggal 30 Oktober 2018. Kegiatan pada pertemuan keempat adalah tes akhir siklus I. Siswa diminta menyelesaikan satu soal uraian tentang materi yang telah dipelajari.

\section{Observasi Tindakan}

Observasi dilakukan oleh dua orang guru yang mengamati aktivitas siswa dan aktivitas guru dengan berpedoman pada lembar observasi yang telah divalidasi. Data hasil observasi aktivitas guru tersaji pada tabel 1.

Tabel 1. Data Hasil Observasi Aktivitas Guru

\begin{tabular}{ccccc}
\hline \multirow{2}{*}{ No } & \multirow{2}{*}{ Observer } & \multicolumn{3}{c}{ Pertemuan ke- } \\
\cline { 4 - 5 } & & Pertama & Kedua & Ketiga \\
\hline 1. & Observer 1 & $92 \%$ & $94 \%$ & $95,83 \%$ \\
2. & Observer 2 & $90,91 \%$ & $94 \%$ & $95,83 \%$ \\
\cline { 1 - 3 } Rata-rata tiap pertemuan & $91,48 \%$ & $94 \%$ & $95,83 \%$ \\
\hline \multicolumn{3}{r}{ Rata-rata } & \multicolumn{3}{c}{$93,77 \%$} \\
\multicolumn{2}{c}{ Kategori rata-rata } & Sangat baik \\
\hline
\end{tabular}

Berdasarkan tabel 1 tersebut dapat disimpulkan bahwa aktivitasguru telah sesuai dengan indikator pengamatan kegiatan guru dan telah memenuhi kriteria keberhasilan tindakan. Sedangkan hasil observasi aktivitas siswa tersaji pada tabel 2.

Tabel 2. Data Hasil Observasi Aktivitas Siswa

\begin{tabular}{ccccc}
\hline \multirow{2}{*}{ No } & Observer & \multicolumn{3}{c}{ Pertemuan ke- } \\
\cline { 3 - 5 } & & Pertama & Kedua & Ketiga \\
\hline 1. & Observer 1 & $77,27 \%$ & $80 \%$ & $88,54 \%$ \\
2. & Observer 2 & $77,27 \%$ & $80 \%$ & $87,50 \%$ \\
\hline \multicolumn{2}{c}{ Rata-rata tiap pertemuan } & $77,27 \%$ & $80 \%$ & $88,02 \%$ \\
\hline \multicolumn{2}{c}{ Rata-rata } & \multicolumn{3}{c}{$81,76 \%$} \\
\multicolumn{2}{c}{ Kategori rata-rata } & Sangat baik \\
\hline
\end{tabular}

Hasil observasi aktivitas siswa pada siklus I berkategori sangat baik. Hal ini berarti siswa telah melakukan kegiatan yang sesuai dengan indikator lembar observasi dan telah memenuhi kriteria keberhasilan tindakan.

\section{Refleksi}

Data hasil observasi aktivitas guru dan siswa serta tes akhir siklus kemampuan komunikasi matematis tulis siswa digunakan sebagai bahan refleksi. Tabel 3 menyajikan hasil keterlaksanaan pembelajaran siklus I. Berdasarkan tabel 3, ada satu kriteria yang belum terpenuhi yaitu tes akhir siklus. Akibatnya siklus I belum berhasil sehingga perlu dilanjutkan ke siklus II.

Tabel 3. Hasil Keterlaksanaan Pembelajaran Siklus I

\begin{tabular}{clll}
\hline No & \multicolumn{1}{c}{ Kriteria } & Hasil & Keterangan \\
\hline 1. & Kegiatan Siswa & Baik & Terpenuhi \\
2. & Kegiatan Guru & Sangat baik & Terpenuhi \\
3. & Tes akhir komunikasi & $60 \%$ siswa mencapai kategori & Tidak terpenuhi \\
& matematis siswa & komunikasi matematis minimal baik & \\
\hline
\end{tabular}




\section{Siklus II \\ Perencanaan Tindakan}

Siklus II dilakukan karena pelaksanaan diklus I belum memenuhi kriteria keberhasilan tindakan yang ditentukan. Sebelum dilaksanakan siklus II, peneliti melakukan perbaikan kekurangan-kekurangan yang terjadi pada siklus I. Adapun perbaikan yang dilakukan adalah seperti yang tersaji pada tabel 4.

Tabel 4. Perbaikan pada Siklus II

\begin{tabular}{ll}
\hline \multicolumn{1}{c}{ Kelemahan Siklus I } & \multicolumn{1}{c}{ Perbaikan pada Siklus II } \\
\hline $\begin{array}{l}\text { Siswa dengan kemampuan komunikasi baik dan sangat baik } \\
\text { lmendominasi dalam pengecekan pengetahuan awal siswa }\end{array}$ & $\begin{array}{l}\text { Guru memberikan kesempatan kepada siswa yang komunikasi } \\
\text { matematisnya tidak baik dan kurang baik pada tahap pengecekan awal }\end{array}$ \\
\hline $\begin{array}{l}\text { Siswa dengan kemampuan komunikasi matematis tidak baik } \\
\text { dan kurang baik kurang aktif dalam diskusi kelompok }\end{array}$ & $\begin{array}{l}\text { Pembentukan kelompok homogen (sesuai dengan kategori kemampuan } \\
\text { komunikasi matematisnya) }\end{array}$ \\
\hline $\begin{array}{l}\text { Setiap siswa mendapatkan LKS, sehingga pada saat diskusi } \\
\text { siswa cenderung mengerjakan sendiri-sendiri }\end{array}$ & $\begin{array}{l}\text { Setiap kelompok mendapatkan dua LKS, kertas karton, spidol sehingga } \\
\text { diskusi antar anggota kelompok lebih aktif }\end{array}$ \\
\hline $\begin{array}{l}\text { Perhatian guru pada siswa yang komunikasinya tidak baik } \\
\text { dan kurang baik rendah }\end{array}$ & $\begin{array}{l}\text { Pendampingan bagi kelompok dengan kategori komunikasi tidak baik dan } \\
\text { kurang baik pada saat pembelajaran }\end{array}$ \\
\hline Penyajian hasil diskusi kelompok belum efektif & $\begin{array}{l}\text { Hasil diskusi dituliskan pada kertas karton dan ditempelkan di papan tulis } \\
\text { dan semua kelompok mengamati hasil diskusi tersebut }\end{array}$ \\
\hline $\begin{array}{l}\text { Partisipasi anak untuk memberikan tanggapan terhadap } \\
\text { penyajian hasil kelompok lain masih kurang }\end{array}$ & $\begin{array}{l}\text { Guru mendorong setiap kelompok untuk memberikan pendapatnya atas } \\
\text { penyajian setiap kelompok dengan memberikan catatan pada lembar } \\
\text { penyajian }\end{array}$ \\
\hline $\begin{array}{l}\text { Siswa belum terbiasa dengan kegiatan refleksi dan tidak } \\
\text { menindaklanjuti hasil refleksi }\end{array}$ & $\begin{array}{l}\text { Guru menekankan kepada siswa untuk mengisi lembar refleksi dengan } \\
\text { jujur dan menindaklanjuti hasil dari refleksi tersebut }\end{array}$ \\
\hline
\end{tabular}

Peneliti melakukan persiapan untuk siklus II meliputi penyusunan RPP lengkap dan instrumen penelitian, dan waktu pelaksanaan penelitian. Siklus II direncanakan selama 2 kali pertemuan pelaksanaan tindakan dan 1 kali pertemuan untuk tes akhir siklus.

\section{Pelaksanaan}

Pelaksanaan siklus II pada tanggal 10, 12, dan 15 November 2018. Pertemuan kelima dilaksanakan pada tanggal 10 November 2018. Kegiatan pembelajaran diawali dengan pemberian motivasi kepada siswa untuk senantiasa semangat belajar dan berusaha semaksimalnya untuk meraih hasil optimal. Selain itu, guru juga menyampaikan hasil tes yang telah dilakukan pada pertemuan tanggal 30 Oktober 2018 dan menyampaikan bagi siswa yang belum mencapai komunikasi yang baik untuk terus meningkatkan belajar dan partisipasinya di kelas. Selanjutnya guru memberikan pertanyaan kepada siswa tentang hasil perkalian $(a-b)(c-d)$. Beberapa siswa merespon pertanyaan guru dan terjadi diskusi antara guru-siswa. Petikan percakapan yang terjadi sebagai berikut.

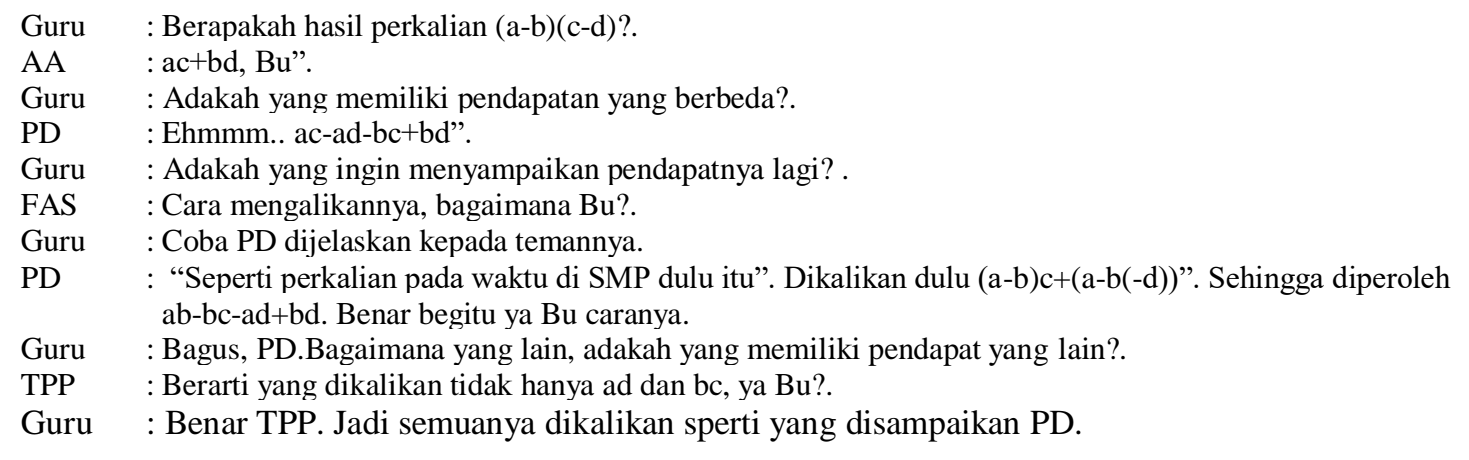

Selanjutnya guru menyampaikan pembagian kelompok sesuai dengan hasil tes akhir dan meminta siswa untuk berkumpul dengan kelompoknya. Kegiatan inti diawali dengan guru menyampaikan bahwa siswa akan belajar cara yang berbeda untuk menentukan selesaian dari sistem persamaan linier tiga variabel dengan mengikuti kegiatan yang ada pada bahan diskusi 10. Guru menyajikan bentuk umum sistem persamaan linier tiga variabel. Selanjutnya, siswa diminta menentukan nilai $x, y$,dan $z$ dari sistem persamaan linier tiga variabel tersebut dalam bentuk perkalian $a b c$ yang merupakan koefisien-koefisien dari variabel $x, y, \operatorname{dan} z$.

Masing-masing kelompok berdiskusi secara aktif. Siswa yang mengalami kesulitan bertanya kepada guru atau teman lain yang telah berhasil menemukan solusinya atau membaca sumber belajar lain untuk menambah referensi. Selama diskusi, guru berkeliling dan mendampingi kelompok siswa yang komunikasi matematis tulisnya kurang baik atau tidak baik. setelah waktu diskusi selesai, siswa diminta untuk menempelkan hasil diskusi kelompoknya di papan tulis. Kemudian setiap kelompok 
diminta memberikan pendapatnya atas hasil diskusi kelompok lain. Bagi kelompok yang belum selesai dalam mengerjakannya, guru meminta kelompok tersebut untuk memperhatikan hasil diskusi kelompok yang telah selesai. Setelah penyajian hasil diskusi selesai, guru bersama siswa menyimpulkan hasil pembelajaran yakni menentukan selesaian sistem persamaan linier tiga variabel dengan metode perkalian koefisien. Selanjutnya, siswa melanjutkan menyelesaikan bahan diskusi 11 dan kemudian menyampaikan hasilnya kepada kelompok lain.

Pertemuan kelima ditutup dengan tes penguasaan materi dan refleksi. Guru mengingatkan kepada siswa untuk melaksanakan kegiatan refleksi dengan mengisi kotak refleksi secara jujur. Siswa juga dihimbau untuk melaksanakan apa yang direncanakan untuk meningkatkan kemampuan komunikasi matematis tulisnya. Guru juga berpesan kepada siswa untuk menambah wawasan tentang sistem persamaan linier melalui buku lain yang relevan atau internet.

Pertemuan keenam dilaksanakan pada tanggal 12 November 2018 dengan kegiatan menyelesaikan soal-soal yang berkaitan dengan sistem persamaan linier tiga variabel dengan metode perkalian koefisien. Pemberian motivasi oleh guru mengawali pertemuan keenam. Guru memotivasi siswa untuk senantiasa meningkatkan ilmu pengetahuan dan memanfaatkan internet untuk pembelajaran. Sebelum masuk kegiatan inti, guru mengingatkan siswa tentang materi yang dipelajari pada pertemuan sebelumnya dengan melakukan tanya jawab. Siswa telah memahami metode-metode yang dapat digunakan untuk menentukan selesaian sistem persamaan linier tiga variabel. Kegiatan pembelajaran dilaksanakan dengan diskusi kelompok, pembagian kelompok tetap seperti pada pertemuan kelima.

Ada tiga bahan diskusi yang disajikan guru pada pertemuan ketiga. Siswa diminta mendiskusikan permasalahan tersebut bersama kelompoknya. Dua masalah yang didiskusikan oleh masing-masing dua orang pada kelompok tersebut, sedangkan satu soal didiskusikan bersama-sama seluruh anggota kelompok. Apabila ada pertanyaan, siswa bertanya kepada teman satu kelompoknya, selanjutnya apabila masih menemui kesulitan siswa bertanya kepada guru. Selama diskusi, guru berkeliling, membimbing, dan mengamati jalannya diskusi. Semua siswa aktif dalam kelompoknya. Siswa dengan komunikasi matematis tulis kurang baik telah menunjukkan peningkatan dalam kemampuan komunikasinya dan aktif dalam diskusi kelompok.

Setelah diskusi selesai, siswa menyajikan hasil diskusinya dan saling memberikan tanggapan atas hasil diskusi kelompok lain. Kegiatan inti selanjutnya adalah guru bersama siswa membuat kesimpulan atas pembelajaran yang telah dilaksanakan dan melihat

Siklus II berakhir pada ketercapaian pembelajaran. Sebagai penutup, guru menyampaikan kepada siswa bahwa tanggal 15 November akan dilaksanakan tes akhir dengan materi sistem persamaan linier tiga variabel. Guru berpesan agar siswa mempersiapkan diri dengan baik. Pertemuan ketujuh dilaksanakan pada tanggal 15 November 2018. Kegiatan pada pertemuan ini adalah tes akhir. Siswa mengerjakan satu soal uraian tentang masalah yang berkaitan dengan sistem persamaan linier tiga variabel. Sebelum tes, guru berpesan agar siswa jujur dan percaya diri dalam menyelesaikan soal uraian yang diberikan.

\section{Observasi Tindakan}

Observasi dilaksanakan bersamaan dengan pelaksanaan tindakan dan dilakukan oleh dua orang observer. Hasil observasi aktivitas guru dan siswa kemudian dianalisis dengan hasil seperti yang tersaji pada tabel 5 dan 6 .

Tabel 5. Hasil Observasi Aktivitas Guru

\begin{tabular}{lccc}
\hline No & Observer & \multicolumn{2}{c}{ Pertemuan } \\
\cline { 3 - 4 } & & Kelima & Keenam \\
\hline 1. & Observer 1 & $98,96 \%$ & $100 \%$ \\
2. & Observer 2 & $98,96 \%$ & $100 \%$ \\
\hline Rata-rata tiap pertemuan & $98,96 \%$ & $100 \%$ \\
\hline \multicolumn{2}{r}{ Rata-rata } & \multicolumn{3}{c}{$99,48 \%$} \\
\multicolumn{2}{c}{ Kategori rata-rata } & \multicolumn{3}{c}{ Sangat Baik } \\
\hline
\end{tabular}

Tabel 6. Hasil Observasi Aktivitas Siswa

\begin{tabular}{lccc}
\hline \multirow{2}{*}{ No } & Observer & \multicolumn{2}{c}{ Pertemuan } \\
\cline { 3 - 4 } & & Kelima & Keenam \\
\hline 1. & Observer 1 & $96,88 \%$ & $98,96 \%$ \\
2. & Observer 2 & $96,88 \%$ & $98,96 \%$ \\
\hline \multicolumn{2}{c}{ Rata-rata tiap pertemuan } & $96,88 \%$ & $98,96 \%$ \\
\hline \multicolumn{2}{r}{ Rata-rata } & \multicolumn{3}{c}{$97,92 \%$} \\
\multicolumn{2}{c}{ Kategori rata-rata } & \multicolumn{3}{c}{ Sangat Baik } \\
\hline
\end{tabular}

Berdasarkan tabel 5 dan 6, dapat disimpulkan bahwa keterlaksanaan kegiatan pembelajaran telah sesuai dengan indikator yang dirumuskan pada lembar observasi aktivitas guru dan aktivitas siswa. O1 dan O2 memberikan catatan bahwa kegiatan pembelajaran berjalan sesuai dengan apa yang direncanakan peneliti dan para siswa telah berpartisipasi aktif dalam kegiatan pembelajaran. 


\section{Refleksi Tindakan}

Keberhasilan tindakan pada siklus II ditentukan oleh hasil observasi aktivitas guru dan aktivitas siswa serta hasil tes akhir kemampuan komunikasi matematis tulis siswa. Tabel 7 menyajikan hasil keterlaksanaan pembelajaran pada siklus II.

Tabel 7. Hasil Keterlaksanaan Pembelajaran pada Siklus II

\begin{tabular}{cccc}
\hline No & Kriteria & Hasil & Keterangan \\
\hline 1. & Kegiatan Siswa & Sangat baik & Terpenuhi \\
2. & Kegiatan Guru & Sangat baik & Terpenuhi \\
3. & Tes akhir komunikasi & 85\% siswa mencapai kategori & Terpenuhi \\
& matematis siswa & komunikasi matematis tulis baik &
\end{tabular}

Berdasarkan tabel 7, hasil keterlaksanaan pembelajaran telah memenuhi kriteria keberhasilan yang ditetapkan. Oleh karena itu, dapat disimpulkan bahwa penelitian tidak perlu dilanjutkan ke siklus berikutnya, penelitian selesai, dan peneliti menyusun laporan penelitiannya.

Adapun temuan penelitian yang diperoleh ketika pelaksanaan siklus I dan II sebagai berikut. Pertama, siswa kurang aktif dalam diskusi kelompok pada pertemuan pertama sehingga diskusi kurang efektif. Kedua, tahap pengecekan pengetahuan awal: siswa dengan komunikasi tidak baik dan kurang baik siswa kurang aktif dan tahap ini masih didominasi oleh siswa dengan komunikasi matematis baik dan tidak baik. Ketiga, pembagian kelompok siswa secara homogen pada siklus II lebih efektif dibandingkan secara heterogen pada siklus I. Keempat, yang mengalami kesulitan pada tahap mendefinisikan variabel mengalami kesulitan pada tahap menyimpulkan. Kelima, keaktifan siswa dalam diskusi kelompok dan penyajian hasil diskusi semakin meningkat pada pertemuan kedua hingga pertemuan keenam. Keenam, tahap refleksi membantu siswa untuk mengetahui materi yang belum dipahami dan menentukan hal yang harus dilakukan dalam belajar.

\section{PEMBAHASAN}

\section{Penerapan Pendekatan Student-Center Learning untuk Meningkatkan Komunikasi Matematis Tulis Siswa}

Penerapan pendekatan student center learning pada materi sistem persamaan linier tiga variabel dilakukan secara diskusi kelompok. Pendekatan student center learning untuk dapat meningkatkan kemampuan komunikasi matematis tulis siswa diawali dengan kegiatan pemberian motivasi, penyampaian cara penilaian, pengecekan pengetahuan awal siswa, dan pembentukan kelompok. Pemberian motivasi dapat berbentuk pemberian contoh penerapan materi sistem persamaan linier tiga variabel dalam kehidupan sehari-hari yang dialami siswa. (Tasgin \& Tunc, 2018) menyatakan bahwa pemberian motivasi pada pembelajaran diperlukan untuk mendorong partisipasi siswa dalam pembelajaran. Selain itu, siswa diberikan kesempatan untuk mencari informasi tentang masalah sistem persamaan linier tiga variabel yang ada dalam kehidupan sehari-hari siswa.

Pemberian motivasi juga dapat dilakukan dengan penyampaian cara penilaian kepada siswa. Siswa diberikan informasi tentang cara penilaian yang digunakan yaitu tes penguasaan materi untuk menentukan pembagian kelompok, tes akhir siklus untuk mengetahui tingkat kemampuan komunikasi matematis tulis siswa. Selain itu, kegiatan siswa selama pembelajaran juga diamati oleh observer. Kegiatan selanjutnya adalah pengecekan pengetahuan awal siswa. Hal ini sesuai dengan psikologi kognitif yang menyatakan bahwa manusia belajar dengan menghubungkan pengetahuan yang telah dimiliki dengan pengetahuan baru (Jacobs et al., 2016). Jika guru mengetahui tingkat pengetahuan awal siswa, maka guru dapat menangani siswa yang pengetahuan awalnya kurang terlebih dahulu sebelum melanjutkannya ke pemberian pengetahuan baru tersebut.

Pengetahuan baru dapat dibangun dengan berlandaskan pada pengetahuan awal siswa (Bingolbali, Akkoc, Ozmantar, \& Demir 2011). Pengecekan pengetahuan awal siswa pada pendekatan ini dilakukan dengan tanya jawab secara klasikal sebelum memulai pembelajaran. Siswa dengan kemampuan komunikasi matematis tulis tidak baik dan kurang baik belum cenderung pasif. Kegiatan ini lebih didominasi oleh siswa dengan komunikasi matematis baik dan sangat baik pada siklus I, sedangkan pada siklus II siswa dengan kemampuan komunikasi kurang baik mulai bepartisipasi aktif dalam kegiatan pengecekan pengetahuan awal. Guru juga membahas tentang tugas yang diberikan kepada siswa.

Sebelum pembelajaran dimulai, siswa dibagi dalam kelompok-kelompok belajar dengan anggota empat siswa setiap kelompok. Pembagian kelompok pada siklus I secara heterogen dalam hal kemampuan komunikasi matematis tulisnya, sedangkan pada siklus II kelompok dibentuk secara homogen. Hal ini sesuai dengan elemen kedua pendekatan student center learning yang dikemukakan oleh (Jacobs et al., 2016), yaitu interaksi antar siswa. Menurut (Walle, 2013), melalui diskusi antar siswa dapat mempelajari ide-ide matematis dari berbagai sudut pandang sehingga pemahaman matematika siswa dapat bertambah. Diskusi kelompok menjadi sarana interaksi antar siswa sehingga dapat meningkatkan kemampuan komunikasi matematis tulisnya dan saling membantu dengan temannya.

Kegiatan inti dimulai dengan siswa mengamati permasalahan yang disajikan oleh guru melalui lembar kegiatan siswa. Masalah yang disajikan guru adalah masalah sehari-hari yang dekat dengan kehidupan siswa, seperti pilihan menu makanan pada Kafe Kang Mus, perencanaan tiket, makanan dan minuman sebagai bekal ketika akan melihat pentas seni. (Norris, 1985) menyatakan bahwa pengamatan sebagai langkah awal siswa dalam menerima informasi merupakan dasar untuk perkembangan keterampilan proses ilmiah lebih lanjut. Hasil dari proses pengamatan ini berupa informasi yang dituliskan pada kotak 
mengumpulkan informasi. Guru menekankan bahwa hanya informasi penting dari soal yang perlu dituliskan. Salah satu kelompok pada pertemuan pertama siklus 1 pada tahap mengumpulkan informasi, kelompok tersebut menuliskan kembali soalnya seperti yang tersaji pada gambar 2 .

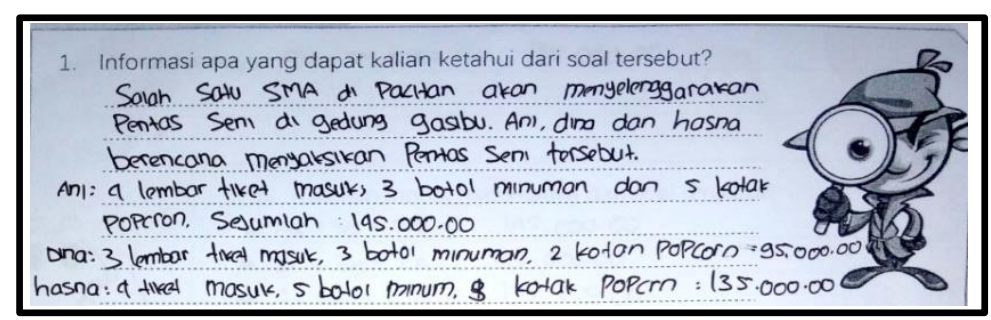

\section{Gambar 2. Jawaban salah satu kelompok pada tahap mengumpulkan informasi}

Selanjutnya adalah siswa menyusun pertanyaan yang mungkin dari informasi yang diperoleh dari masalah yang disajikan. Pelaksanan pengumpulan informasi pada kegiatan kelompok siklus I dilaksanakan secara individu. Siswa dengan komunikasi kurang baik dan tidak baik hanya memperhatikan dan mencontoh jawaban dari teman yang memiliki kemampuan komunikasi tulis baik atau sangat baik. Hal ini menjadi salah satu penyebab siswa tidak tepat dalam mendefinisikan variabel. Tahapan selanjutnya adalah menyelesaikan masalah yang disajikan berdasar informasi dan pertanyaan yang telah dilakukan. Penyelesaian masalah diawali dengan siswa mendefinisikan variabel-variabel dari masalah kontekstual, menyusun model matematika, menuliskan ide solusi/selesaian, dan menuliskan simpulan dari selesaian yang diperoleh.

Setelah diskusi selesai, guru membimbing siswa untuk menyajikan hasil diskusi kepada kelompok lain. Penyajian hasil diskusi pada siklus I dilakukan dengan mengunjungi kelompok lain. Akan tetapi, pada pelaksanaannya tidak semua anggota kelompok aktif dalam diskusi. Pentajian hasil dikusi pada siklus II diperbaiki yaitu dengan menempel hasil diskusi di papan tulis dan setiap kelompok memberikan pendapatnya atas hasil diskusi kelompok lain. Cara ini dapat mengaktifkan komunikasi matematis tulis siswa karena setiap anggota kelompok memiliki tanggung jawab untuk menyajikan yang terbaik. Penyajian haisl diskusi menurut (Kemdikbud, 2014) merupakan salah satu bentuk kegiatan mengomunikasikan. Tahap selanjutnya adalah membuat kesimpulan pelaksanaan pembelajaran.

Pembelajaran ini ditutup dengan kegiatan tes pengetahuan materi dan refleksi. Kegiatan mengevaluasi materi sesuai dengan elemen ke-8 dari student center learning (Jacobs, Renandya, \& Power, 2016) yang menyatakan bahwa penilaian secara terus menerus perlu dilakukan. Kegiatan tes penguasaan materi dilaksanakan satu kali pada siklus I dan II, sedangkan kegiatan refleksi sesuai dengan prinsip I dari pendekatan student center learning (Attard, dkk., 2010), yaitu SCL memerlukan refleksi terus menerus. Guru membimbing siswa dalam melakukan refleksi dengan bantuan pertanyaan pada kotak refleksi. Kegiatan refleksi dapat terlaksana pada pertemuan kedua hingga keenam. Kegiatan refleksi ini mendorong siswa untuk mengetahui apa yang harus dilakukannya ketika siswa mengalami kesulitan dalam belajarnya.

\section{Peningkatan Kemampuan Komunikasi Matematis Tulis Siswa setelah Pendekatan Student Center Learning}

Kegiatan siswa setelah satu siklus berakhir adalah tes akhir siklus. Tes akhir siklus, baik pada siklus I maupun II terdiri dari satu soal uraian yang disusun berdasarkan indikator kemampuan komunikasi matematis tulis siswa. Indikator kemampuan komunikasi matematis tulis siswa materi sistem persamaan linier tiga variabel yang digunakan pada penelitian ini adalah (1) mendefinisikan variabel-variabel dari masalah kontekstual, (2) menyusun model matematika dari masalah kontekstual yang berkaitan dengan sistem persamaan linier tiga variabel, (3) menuliskan ide/gagasan penyelesaian, (4) menuliskan simpulan dari selesaian yang diperoleh. Setelah tes selesai, hasil tes akhir siklus dianalisis dengan analisis kuantitatif dan dikelompokkan sesuai dengan kategorinya. Persentase peningkatan kemampuan komunikasi matematis tulis siswa dari tes awal hingga siklus II tersaji pada tabel 8 .

\begin{tabular}{ccc} 
Tabel 8. Persentase Peningkatan Kemampuan Komunikasi Matematis Siswa \\
\hline Tindakan & $\begin{array}{c}\text { Rata-rata persentase } \\
\text { secara kelas }\end{array}$ & $\begin{array}{c}\text { Pencapaian secara } \\
\text { klasikal }\end{array}$ \\
\hline Tes awal & $44,69 \%$ & $15 \%$ \\
Tes siklus I & $64,79 \%$ & $60 \%$ \\
Tes Siklus II & $80,83 \%$ & $85 \%$ \\
\hline
\end{tabular}

Berdasarkan tabel 8, siswa yang memiliki kemampuan komunikasi matematis tulis minimal baik dari tes awal, siklus I, dan siklus II mengalami peningkatan. Demikian juga rata-rata persentase secara kelas juga mengalami peningkatan sebesar 20,1\% dari tes awal ke siklus I, dan 16,04\% dari siklus I ke siklus II. Sementara itu, pencapaian secara klasikal mengalami kenaikan sebesar $45 \%$ dari tes awal ke siklus I, dan $25 \%$ dari siklus II. 
Selain pada kemampuan komunikasi matematis tulis yang meningkat, peningkatan juga terjadi pada keterlaksanaan pembelajaran. Keterlaksanaan pembelajaran ditinjau dari hasil observasi aktivitas guru dan aktivitas siswa yang dianalisis dari lembar observasi. Hasil analisis tersebut tersaji pada tabel 9. Berdasarkan tabel 9 tersebut, dapat disimpulkan bahwa perbaikan yang diterapkan pada siklus II dapat meningkatkan 5,71\% aktivitas guru dan 16,16\% aktivitas siswa pada kegiatan pembelajaran.

Tabel 9. Persentase Peningkatan Keterlaksanaan Aktivitas Guru dan Siswa dari Siklus I ke Siklus II

\begin{tabular}{lllll}
\hline Tindakan & $\begin{array}{c}\text { Nilai Persentase } \\
\text { Aktivitas Guru }\end{array}$ & Peningkatan & $\begin{array}{c}\text { Nilai Persentase } \\
\text { Aktivitas Siswa }\end{array}$ & Peningkatan \\
\hline Siklus I & $93,77 \%$ & $5,71 \%$ & $81,76 \%$ & $16,16 \%$ \\
Siklus II & $99,48 \%$ & $97,92 \%$ & \\
\hline
\end{tabular}

\section{SIMPULAN}

Berdasarkan hasil penelitian dan pembahasan, dapat disimpulkan bahwa langkah-langkah pendekatan student center learning yang dapat meningkatkan komunikasi matematis tulis siswa SMA terdiri atas (1) kegiatan pendahuluan terdiri dari pemberian motivasi, penyampaian cara penilaian, pengecekan kemampuan awal, dan mengorganisir siswa ke dalam kelompok belajar; (2) kegiatan inti terdiri dari mengamati masalah yang disajikan guru, mengumpulkan informasi, menyusun pertanyaan, menyelesaikan masalah, menyajikan hasil diskusi; (3) kegiatan penutup yaitu tes penguasaan materi dan refleksi. Pemberian motivasi berguna untuk mendorong partisipasi siswa dalam pembelajaran yang sangat diperlukan pada diskusi dan penyajian hasil diskusi. Guru memberikan motivasi dengan menyampaikan contoh masalah sistem persamaan linier tiga variabel dalam kehidupan sehari-hari. Sementara itu, penyampaian cara penilaian dapat memotivasi siswa untuk lebih giat belajar dan aktif dalam diskusi kelas. Pengecekan kemampuan awal diperlukan agar guru dapat menangani siswa yang memiliki kemampuan awal kurang. Pembentukan kelompok secara homogen lebih efektif dibandingkan secara heterogen.

Berdasarkan hasil penelitian dan temuan penelitian yang diperoleh ketika penerapan pendekatan student center learning untuk meningkatkan kemampuan komunikasi matematis tulis siswa SMA perlu disampaikan beberapa saran, yaitu (1) guru perlu mendampingi siswa kemampuan komunikasi matematis tulis kurang baik pada saat diskusi kelompok; (2) tahap refleksi, guru perlu mengingatkan siswa dalam menindaklanjuti hasil refleksi.

\section{DAFTAR RUJUKAN}

Baroody, A. (1993). Problem Solving, Reasoning, and Communicating, K-8. HElping Children Think Mathematically. New York: Mcmillan Publishing

Bingolbali, E., Akkoc, H., Ozmantar, M. F., \& Demir, S. (2011). Pre-Service and In-Service Teachers" Views of the Sources of Student" Mathematical Difficulties. International Electronic Journal of Mathematics Education, 6(1), 40-59.

Cai, J., Jakabcsin, M. S., \& Lane, S. (2016). Assessing Students' Mathematical Communication Assessing Students Mathematical Communication. School Science and Mathematic, 96(5), 238-246. https://doi.org/10.1111/j.19498594.1996.tb10235.x

Erhan, S., \& Nahornick, A. (2016). Teaching and Learning Mathematics Series I : Effective Instructional Strategies. Toronto, Canada.

Hsiao, E. L., Mikolaj, P., \& Shih, Y. T. (2017). A Design Case of Scaffolding Hybrid/Online Student-Centered Learning With Multimedia. Journal of Educators Online, 14(1), 1-9.

Jacobs, G. M., Renandya, W. A., \& Power, M. (2016). Simple, Powerful Strategies for Student Centered Learning. Springer Natureh. https://doi.org/10.1007/978-3-319-25712-9

Kemendikbud. (2016). Peraturan Menteri Pendidikan dan Kebudayaan Nomor 21 Tahun 2016 Tentang Standar Isi Pendidikan Dasar dan Menengah Standar Isi. 44(4), 447-678.

Martell, C. (2015). Age of Creative Insecurity: Student-Centered Learning. Journal of Education for Library and Information Science, 56(1), 112-120.

Pantaleon, K., Juniati, D., Lukito, A., \& Mandur, K. (2018). The Written Mathematical Communication Profile of Prospective Math Teacher in Mathematical Proving. Journal of Physics: Conference Series, 947, 1-6. doi :10.1088/1742$6596 / 947 / 1 / 012070$

Rajagukguk, W. (2016). Incorporating Learning Motivation and Self-Concept in Mathematical Communicative Ability. International Education Studies, 9(4), 155-164. https://doi.org/10.5539/ies.v9n4p155

Saragih, S. (2007). Mengembangkan Kemampuan Berpikir Logis dan Komunikasi Matematika Siswa Sekolah Menengah Pertama melalui Pendekatan Matematika Realistik. Disertasi tidak diterbitkan. Universitas Pendidikan Indonesia, Bandung.

Tasgin, A., \& Tunc, Y. (2018). Effective Participation and Motivation : An Investigation on Secondary School Students. World Journal of Education, 8(1), 58-74. https://doi.org/10.5430/wje.v8n1p58 